\title{
Is Green Marketing a Basis for Purchase Decisions
}

\author{
$1^{\text {st }}$ Humairoh \\ Department of Economic and Business \\ Universitas Muhammadiyah \\ Tangerang \\ Tangerang, Indonesia \\ *mairamamay48@gmail.com
}

\author{
$2^{\text {nd }}$ Nur Maulida Elfani \\ Department of Economic and Business \\ Universitas Muhammadiyah \\ Tangerang \\ Tangerang, Indonesia
}

\begin{abstract}
The research aims to eximine the influence of green products and green advertising on purchasing decisions on Tupperware in Kelapa Dua Tangerang as simultaneously and partially. The research in this study has three hypotheses. This study is a causal study to obtain evidence of a causal relationship. The sampling technique used was a purposive sampling method with a questionnaire as an instrument to collect data and the results were processed using the Scala Likert Summated Rating method with a score of 1 - 5. Respondents in this study were Tupperware Kelapa Dua Tangerang City, Banten Province. Respondents from 71 customers were interviewed based on statements in the questionnaire. This study used path analysis techniques using SPSS software version 20. The research method uses multiple linear regression analysis methods, determination analysis (R2), $t$ test and $F$ test analysis to test partial and simultaneous hypotheses. The results showed that the variables of green products and green advertising had a significant and positive effect on purchasing decisions simultaneously and partially. Green products and green advertising have a strong correlation with purchasing decisions.
\end{abstract}

\section{Keywords-Green Marketing, Purchase Decision}

\section{INTRODUCTION}

The rapid development of business today is accompanied by an increasingly complex environmental problems. One of the main environmental problems facing society today is waste pollution. In various cases, the waste problem is very dominant in various developing countries. Waste becomes a problem for the environment because the amount is very large and difficult to recycle. According to data released by the Ministry of Environment and Forestry, the increase in waste dumps in Indonesia has reached 175,000 tons / day or the equivalent of 64 million tons / year and is increasing every year [1].

Environmental problems have become a strategic issue to be studied and resolved by various parties at this time in an effort to protect the environment that is increasingly growing in line with consumer awareness. The increasing amount of waste has made the government and producers begin to consider the need to use environmentally friendly and recyclable products. With this awareness, the company applies environmental issues as one of its marketing strategies or what we already know as green marketing. Attention to environmental issues is evident from the increasing market that cares for the environment. Attention to environmental issues is marked by the rise of business people in applying international standards or better known as ISO-14000. ISO-14000 is an environmental management system that can provide guarantees (evidence) to producers and consumers that by implementing the system the products produced / consumed either waste, used products, or services have gone through a process that takes into account the rules or efforts. environmental management efforts.

Companies and consumers are parties who play a role in protecting the environment. In such conditions, one of the company's strategies is to produce a variety of products that use materials that do not damage the environment or are known as green products. At this time companies that apply green products are increasingly developing to attract consumers' interest in these products. The company's efforts can influence consumers to have awareness and buy products that are environmentally friendly [2][3].

The company's effort in campaigning for green products is by increasing the role of green advertising, this is intended to increase public awareness in protecting the environment. The company's strategy in increasing the role of green advertising can be done by creating advertisements that contain content that is concerned about environmental sustainability, for example companies can embed natural images, slogans care about the environment, include images of environmental sustainability to include the impact of a lack of awareness of environmental sustainability. According to Zinkhan and Carlson (1995) [4] states "green advertising as promotional messages that may appeal to the needs and desires of environmentally concerned consumers". Decision making is the most important process of consumer behavior, marketers must truly understand how consumers make decisions [5]. The existence of a green advertising strategy in advertising is expected to provide positive information to consumers, which is expected to have positive information that will form a positive product brand image also consumers' minds, the next action taken by consumers after that is to make a purchasing decision.

The study of the concept of green marketing has been conducted by a number of researchers. [6] The green advertising does not directly influence decisions, but the presence of green advertising will make the brand image of the product better in the eyes of consumers. [7] The green products directly influence buying interest, while green advertising influences buying interest through consumer perceptions. Consumer awareness of green- 
based products, advertising and brands have a positive and significant effect on purchasing decisions [8].

In accordance with the background and previous research, the purpose of this study is to analyze the effect of green products and green advertising on purchasing decisions both partially and simultaneously. The fundamental difference from previous studies on the variables used are green products and green advertising on purchasing decisions. The results of this study are expected to provide scientific information and also as a reference in learning and developing green marketing to improve gifting decisions.

\section{METHOD}

\begin{tabular}{|c|c|c|}
\hline Variable & Indicator & Source \\
\hline \multirow{3}{*}{$\begin{array}{l}\text { Green product } \\
\text { (X1) }\end{array}$} & Product perception & \multirow{3}{*}{ (Junaidi, 2005 [9]) } \\
\hline & Packaging & \\
\hline & Composition of contents & \\
\hline \multirow{3}{*}{$\begin{array}{l}\text { Green advertising } \\
\text { (X2) }\end{array}$} & $\begin{array}{l}\text { information on eco-labels is easy to } \\
\text { understand }\end{array}$ & \multirow{3}{*}{ (Pawitaningtyas, 2019 [6]) } \\
\hline & Promote lifestyle & \\
\hline & Display the company image & \\
\hline \multirow{5}{*}{ Purchasing decision (Y) } & Knowledge needs & \multirow{5}{*}{ (Ridwan, 2018 [8]) } \\
\hline & Information search & \\
\hline & Alternative evaluation & \\
\hline & Deciding to buy & \\
\hline & Positive Post-Purchase Behavior & \\
\hline
\end{tabular}

The approach used in this study is quantitative research, which is a reseach method based on the philosophy of positivism, used to eximine certain population or samples, data collection using research instruments, quantitative/ statistical data analysis, with the aim of testing the predetermined hypothesis [10]. The type of research used in causal research.

The type of data used in this study is primary data. Primary data is obtained by researcher from the first source, either individuals or individuals such as the result of interviews or filling out quesionnaires that are usually carried out by researchers. To obtain this data, researcher distributed quesionnaires to customers of Tupperware product in kelapa Dua, Tangerang City, Banten Province. The statement in the quesionnaire were made using the semantic likert scale range 1-5. The sampling technique used in is purposive sampling. The number of samples taken in this study uses 71 samples.

\section{RESULT}

\section{A. T-test}

$\mathrm{T}$ test (partially) is used to determine the significance of the effect of each independent variable partially on a dependent variable. In the green product variable $(\mathrm{X} 1)$ to the purchase decision (Y), based on the table 2 is obtained t count of 5,126 , with a significance level $<5 \%$. Thus, it can be concluded that $\mathrm{t}$ count $>$ from t table $(5,126>$ 1,994) where a significant value of $0,000<0,05$ then Ho is rejected and H1 is accepted, which means that green product (X1) has a positive and significant effect on purchasing decisions $(\mathrm{Y})$. In the green advertising variable (X2) is obtained t count of 13,488 , with a significance level $<5 \%$. Thus, it can be concluded that $t$ count $>$ from $t$ table $(13,488>1,994)$ where a significant value of 0,000 $<0,05$ then Ho is rejected and H2 is accepted, which means green advertising (X2) has a positive and significant effect on purchasing decisions (Y).

TABLE 2. RESULTS OF MULTIPLE LINEAR REGRESSION ANALYSIS ON PURCHASING DECISIONS

\begin{tabular}{|c|c|c|c|c|c|c|}
\hline Variable & $\begin{array}{c}\text { Regressio } \\
n \\
\text { Coefficien } \\
t\end{array}$ & $\begin{array}{l}\text { Std. } \\
\text { Error }\end{array}$ & $\begin{array}{c}\text { Bet } \\
\mathrm{a}\end{array}$ & $\begin{array}{c}\mathrm{t} \\
\text { count }\end{array}$ & Sig. & $\begin{array}{c}\text { Significanc } \\
\mathrm{e}\end{array}$ \\
\hline Constant &, 525 & $\begin{array}{c}2,79 \\
8\end{array}$ & & & $\begin{array}{c}855 \\
2\end{array}$ & \\
\hline $\begin{array}{l}\text { Green } \\
\text { product }\end{array}$ & ,276 & ,54 & ,307 & 5,126 & $\begin{array}{c}, 00 \\
0\end{array}$ & Accepted \\
\hline $\begin{array}{l}\text { Green } \\
\text { advertisin } \\
\mathrm{g}\end{array}$ & 1,133 & ,84 & ,809 & $\begin{array}{c}13,48 \\
8\end{array}$ & $\begin{array}{c}, 00 \\
0\end{array}$ & Accepted \\
\hline
\end{tabular}

B. F-Test

TABLE 3. F-TEST RESULTS

\begin{tabular}{|l|r|r|r|r|r|}
\hline \multicolumn{7}{|c|}{ ANOVA $^{\mathbf{a}}$} & Df & Mean Square & F & \multicolumn{1}{c|}{ Sig. } \\
\hline \multicolumn{1}{|c|}{ Model } & Sum of Squares & \multicolumn{1}{c|}{. } & 512,239 & 105,068 &, $000^{\mathrm{b}}$ \\
\hline Regression & 1024,479 & 2 & 4,875 & & \\
\hline Residual & 331,521 & 68 & & & \\
\hline Total & 1356,000 & 70 & & \\
\hline a. Dependent Variable: purchasing decision \\
b. Predictors: (Constant), green advertising, green product \\
\hline
\end{tabular}

Based on table 3, the $\mathrm{f}$ count is 105,068 with alpha < $5 \%$. When compared with $f$ table of 3,13 , it can be concluded that $\mathrm{f}$ count $>\mathrm{f}$ table. This means that Ho is rejected and $\mathrm{H} 3$ is accepted, then the results of the $\mathrm{F}$ test 
can be used to predict purchasing decisions (Y) or it can be said that the green product (X1) and green advertising
(X2) variables together have a positive and significant effect on the return decision $(\mathrm{Y})$.

\section{Determination test}

TABLE 4. DETERMINATION TEST RESULTS ON PURCHASING DECISIONS

\begin{tabular}{|c|r|r|r|r|}
\hline \multicolumn{1}{|c|}{ Predictors } & $\mathrm{R}$ & R Square & \multicolumn{1}{|c|}{$\begin{array}{c}\text { Adjusted R } \\
\text { Square }\end{array}$} & $\begin{array}{c}\text { Std. Error of the } \\
\text { Estimate }\end{array}$ \\
\hline $\begin{array}{l}\text { Green product, Green } \\
\text { advertising }\end{array}$ &, $869^{\mathrm{a}}$ &, 756 &, 748 & 2,20801 \\
\hline
\end{tabular}

Based on table 4, When viewed from $\mathrm{R}$, it can be concluded that the green product and green advertising variables have a strong relationship with purchasing decisions. If base on the coefficient of determination $(\mathrm{R}$ square) is 0,756 . This shows that customer purchasing decisions can be explained by green product (X1) and green advertising (X2) variables by $75,6 \%$ and the remaining $24,4 \%$ is explained by other variables not examined in this study.

\section{DISCUSSION}

\section{A. The effect of green product on purchasing} decisions

The results of the regression analysis (table 2) in the $t$ test show that the green product variable is stated to have a significant effect on product purchasing decisions with a significance value of 0,000 . This states that green products or environmentally friendly products from Tupperware have an important role in purchasing decisions. Regression coefficient of 0,276 indicates that every increase of 1 unit of green product variables will increase purchasing decisions by 0,276 . This shows that the better green product, the higher the purchase decision. This is in line with the research of Imam Santoso, 2015 and Muhammad Ridwan, 2018 that purchasing decisions are influenced by green products. This is because the level of public awareness of environmentally friendly products to meet their needs and desires. Consumers are trying to buy products that at least reduce the negative impact on the environment. The results of this study support the theory of David Wigner (2007) [11]; D'Souza et al (2006) [7] that companies that develop green products can attract consumers to buy these products. The company considers that by implementing green products consumers will be more interested and motivated and increase the purchase interest in products that are considered to have more concern for the environment.

The results of this study reveal that green products which include Tupperware indicators are better than similar products (score 4,43, highest score). Green products generally use selected raw materials that have good quality and benefits for consumers' health and for environmental sustainability. Consumers assume that consuming green products provides a sense of security and is considered healthier (score 3,95). Then in the Tupperware product statement is a product that can be recycled (reusable) has a score of 4,21, and the Tupperware product statement does not use materials that can damage the environment (can be recycled). Green products have many benefits for the environment including reducing pollution and air pollution resulting from the production process. Packaging on green products that are environmentally friendly and can be recycled can reduce the amount of waste that is around us. In addition, green products can also save energy during the production process. Consumers assume that consuming or using green products can directly contribute to reducing the amount of environmental pollution. Green products can save energy and can reduce or eliminate the use of toxic agents, pollution, and waste [12]. Even so, consumers need high costs for consuming or using green products [13] compared to ordinary products (score 3,81 ).

\section{B. The effect of green advertising on purchasing decisions}

The $\mathrm{t}$ test results in table 2 show that the green advertising variable is declared significant towards the purchase decision with a significance value of 0,000 . This means that green advertising or environmentally friendly advertising owned by Tupperware has an important role in consumer purchasing decisions. The results of this study are in line with the results of Muhammad Ridwan's study conducted in 2018. in this study the resulting regression coefficient of 1,133 indicates that every 1 unit increase in the variable green advertising will increase purchasing decisions by 1,133 . This shows that the higher the green advertising, the higher purchasing decisions will result. The results of this study indicate that the purpose of Tupperware advertising that invites consumers to care for the environment, the message framework in advertisements, the message elements in advertisements, the benefits and supporting factors of Tupperware brand product packaging advertising can drive purchasing decisions. Shimp (2001) [8] argues that green advertising can be included in a series of elements used to communicate the concern of a company or product to the environment.

Based on the mean indicator of the green advertising variable revealed that respondents rated Tupperware advertising to provide motivation to care for the environment (score 4,12). At companies, the implementation of green advertising is realized in ecolabeling. Rex \& Bauman (2007) [7] assess eco-label as a tool to help motivational takers to buy green products and provide information about products. At this time, consumers assume that buying products that have eco- 
labels means contributing to protecting the environment. Companies that have eco-labels can increase market share of green products. The high level of consumer concern about environmental damage, with green advertising that is oriented towards the environment can contain one or more of the following things, green color, landscapes, eco-labels, statements of concern for the environment, renewal of raw materials, efficient production processes, can recycled, and green lifestyles provide consumers with awareness of the importance of using environmentally friendly products with a score of 4,30.

It can be concluded that respondents pay attention to the elements or messages conveyed in the advertisement before making a purchase decision, because green advertising is one form of advertising that promotes a green product to attract consumers who care about the environment in meeting their needs and desires for friendly products environment (Zinkhan and Carlson, 1995) [4].

\section{The effect of green product and green advertising on purchasing decisions}

The results of simultaneous testing ( $F$ test) obtained a significance value of 0,000 , it is evident that the variable green product and green advertising simultaneously have a significant effect on purchasing decisions (table 3). Based on the results of simultaneous regression analysis, the variable with a greater influence on purchasing decisions is the green advertising variable $(1,133)$ compared to the green product variable $(0,276)$. this shows the customer before buying a green product, the customer is interested in the advertisements provided by the company. Based on the mean purchase decision variable indicators reveal that respondents get information on Tupperware products which are green products from catalogs, websites and friends (score 4,30) then find out Tupperware product information compared to similar products (score 4,14) then decide to buy based on experience from friends, family and other people (score 4,15). [14] Consumer purchasing decisions in buying preferred brands in various ways there. Decision making as an important process in consumer behavior is very important for the market to understand. The results of green product and green advertising research on purchasing decisions are also supported by previous research conducted by Muhamad Ridwan (2018) which states that green product and green ddvertising have a positive effect on purchasing decisions.

The coefficient of determination of 0,756 (table 4 ), this explains that the green product and green advertising variables are able to explain the decision making variable by $75,6 \%$, the remaining $24,4 \%$ is explained by other variables not examined in this study.

\section{CONCLUSION AND RECOMENDATION}

\section{A. Conclusion}

Green product variable has a positif and significant effect on purchasing decision variables on Tupperware Kelapa Dua branch products. Green products are proven to influence purchasing decisions positively and significantly, consumers' perceptions of Tupperware green products as better products than other similar products, products that can be made from recycled materials and products that do not use materials that can damage the environment so that affect product purchasing decisions Tupperware.

Green advertising variable has a positif and significant effect on purchasing decision variables on Tupperware Kelapa Dua branch products. Green advertising is proven to influence purchasing decisions positively and significantly, consumers' perception of green advertising as advertising provides awareness of the importance of using environmentally friendly products and as an advertisement that gives motivation to care and love the environment so that it influences purchasing decisions of Tupperware products.

The simultaneous influence of green product variables and green advertising variables on the purchase decision variables using the F-test. From the results of multiple linear regression analysis obtained green product variables and green advertising variables have a positif and significant effect on the purchase decision variables simultaneously, so it can be concluded that testing of the hypothesis which states that the influence of green product and green advertising has a significant influence on purchasing decisions can be accepted and it can be concluded that the more positive the two variables are, the more positive the decision to purchase Tupperware products.

\section{B. Recomendation}

Based on the conclusions and discussions obtained from the results of the study, researchers sought to provide input that could be used as reference material for companies related to the green product and green advertising business. Some of the inputs that the researchers want to convey are as follows. Recommendations for green products :

- Tupperware products must add and reproduce other types of designs so that consumers do not get bored with the products offered;

- It should be easier for companies to provide a stage in exchanging damaged Tupperware products to be replaced with new products; and

- Companies must more often provide information and socialize about their products that can be recycled, not harmful to humans, animals and the surrounding environment.

\section{Recommendations for green advertising :}

- Companies can provide more information about slogans in electronic media, print media and social media such as about environmentally friendly lifestyles and the importance of protecting the environment;

- Companies can provide a clear explanation about their products with a lifetime guarantee, such as in the catalog, on social media, so that consumers can find out if the product has a lifetime guarantee; and 
- Companies can provide more information about their products through advertisements on television, social media and print media in more attractive advertisements.

\section{REFERENCES}

[1] N. F. $\quad \mathrm{Al} \quad$ Bahriyatul, "https://ekonomi.bisnis.com/read/20190221/99/891611/timbulan -sampah-nasional-capai-64-juta-ton-per-tahun.” .

[2] E. M. Okada and E. L. Mais, "Framing the 'Green' alternative for environmentally conscious consumers," Sustain. Accounting, Manag. Policy J., 2010.

[3] R. P. Saxena and P. K. Khandelwal, "Greening of industries for sustainable growth: An exploratory study on durable, non-durable and services industries," Int. J. Soc. Econ., 2012.

[4] A. R. Natekar, "Social Networking: an Imminent Tool for Marketing," Intercont. J. Mark. Manag., 2016.

[5] J. P. Peter and J. C. Olson, Consumer behavior and marketing strategy: J. Paul Peter; Jerry C. Olson. 2002.

[6] Pawitaningtyas M R, "effect of green advertising on brand image and its impact on purchasing decisions (Survey on public library visitors and Malang City archives consumer aqua bottled mineral water)," J. Bus. Adm., vol. 25, no. 1, 2019.

[7] I. Santoso and R. Fitriani, "Green Packaging, Green Product, Green Advertising, Persepsi, dan Minat Beli Konsumen," J. Ilmu Kel. dan Konsum., 2016.

[8] Ridwan M, "The effect of green product, green advertising and green brand on purchasing decisions," J. Bus. Adm., vol. 55, no. 1, 2018.

[9] S. R, "Application of green marketing," JIBEKA J., vol. 7, no. 3, 2013.

[10] Sugiyono, "Quantitative, qualitative and R \& D research methods," Alfabeta. 2012.

[11] R. Berta, "Increasing the value of Indonesian original brands with green branding," J. Bus. Adm., vol. 55, 2011.

[12] A. Pankaj and K. L. Vishal, "Consumer Adoption of Green Products and Their Role in Resource Management," Indian J. Commer. Manag. Stud., 2014.

[13] T. Chen and L. Chai, "Attitude towards the environment and green products: Consumers' perspective," Manag. Sci. Eng., 2010.

[14] P. Kotler, K. Keller, and K. L. keller Kotler, Philip, Marketing Management 13th edition. 2012. 